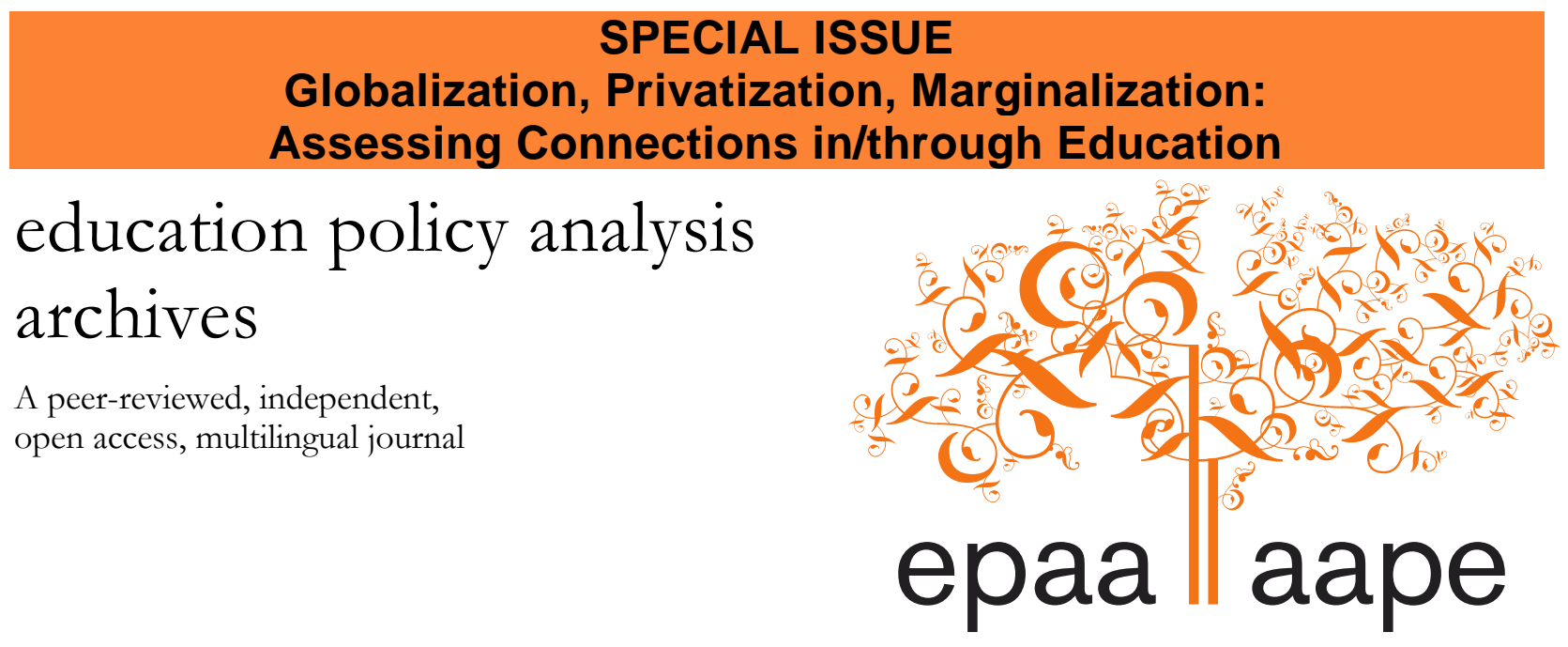

Arizona State University

Volume 27 Number $125 \quad$ October 14, 2019

ISSN 1068-2341

\title{
Education Governance and Privatization in Portugal: Media Coverage on Public and Private Education
}

\author{
Fátima Antunes \\ Centro de Investigação em Educação (CIEd), Universidade do Minho \\ \&o \\ Sofia Viseu \\ UIDEF, Instituto de Educação, Universidade de Lisboa \\ Portugal
}

Citation: Antunes, F., \& Viseu, S. (2019). Education governance and privatization in Portugal:

Media coverage on public and private education. Education Policy Analysis Archives, 27(125).

https://doi.org/10.14507/epaa.27.4293 This article is part of a special issue, Globalization,

Privatization, Marginalization: Assessing Connections in/through Education, Part 1, guest edited by D.

Brent Edwards and Alex Means.

Abstract: This paper aims to discuss recent changes in Portugal's education policy.

Portugal offers an interesting scenario to study the different ways the economic crisis has brought new opportunities to strengthen the privatization agenda. We specifically focus on media coverage and the contractualization of education services with private schools through 'association contracts'. In the 1980s the Portuguese State through these contracts financed private schools to operate in areas where the public offering was insufficient, thereby ensuring the public access to education and preventing marginalization. Nowadays, however, these contracts are seen as an ideological banner both for and against education privatization. We present an empirical study based on documental analysis of 180 news articles published in the Portuguese media on the changes in the contractualization of 
education services. The results show two main audiences sustaining distinct societal projects, comprised of a variety of actors, who are either for or against 'association contracts'. The actors justify their positions based on their understanding of the State's role in providing education, the policies involving the right to education and decreasing inequalities.

Keywords: Globalization; privatization; marginalization; media coverage; association contracts; Portugal

\section{Gobernanza de la educación y privatización en Portugal: La cobertura mediática sobre educación pública y privada}

Resumen: Este artículo analiza cambios recientes en la política de educación en Portugal. Portugal ofrece un escenario interesante para estudiar las diferentes formas en que la crisis económica ha traído nuevas oportunidades para fortalecer la agenda de privatización. Enfocamos específicamente la cobertura mediática y la contratualización de servicios de educación con escuelas privadas a través de ‘contratos de asociación'. En los años 80, el Estado portugués a través de estos contratos ha financiado escuelas privadas para operar en áreas donde la oferta pública era insuficiente, a fin de garantizar el acceso público a la educación y prevenir la marginalización. Hoy, sin embargo, estos contratos se ven como una bandera ideológica a favor y contra la privatización de la educación. Se presenta un estudio empírico basado en el análisis de 180 artículos publicados en la prensa portuguesa sobre los cambios en la contratación de estos servicios educativos. Los resultados muestran dos audiencias principales que sostienen proyectos societales distintos, incluyendo una variedad de actores, que están a favor o en contra de los contratos de asociación. Los actores justifican sus posiciones en base a su comprensión del papel del Estado en la educación, de las políticas que implican el derecho a la educación y la reducción de las desigualdades.

Palabras-clave: Globalización; privatización; marginalización; cobertura mediática; contratos de asociación; Portugal

\section{Governação da educação e privatização em Portugal: A cobertura mediática sobre educação pública e privada}

Resumo: Este artigo pretende discutir mudanças recentes na política educativa em Portugal. Portugal oferece um cenário interessante para estudar diferentes formas pelas quais a crise económica trouxe novas oportunidades para reforçar a agenda de privatização. Focamos especificamente a cobertura dos media e a contratualização de serviços de educação com escolas privadas através de 'contratos de associação'. Nos anos 80, o Estado Português através destes contratos financiava escolas privadas para operar em áreas onde a oferta pública era insuficiente, garantindo assim o acesso público à educação e prevenindo a marginalização. Hoje, no entanto, esses contratos são vistos como uma bandeira ideológica a favor e contra a privatização da educação. Apresentamos um estudo empírico baseado na análise de 180 artigos publicados na imprensa portuguesa sobre as mudanças na contratualização destes serviços de educação. Os resultados mostram duas audiências principais que sustentam projetos societais distintos, incluindo uma variedade de atores, que são a favor ou contra 'contratos de associação'. Os atores justificam as suas posições com base na sua compreensão do papel do Estado na educação, das políticas que envolvem o direito à educação e a redução das desigualdades.

Palavras-chave: Globalização; privatização; marginalização; cobertura mediática; contratos de associação; Portugal 


\section{Introduction}

This paper discusses recent changes in Portugal's education policy with regards to the evolution of private school financing ${ }^{1}$. This area of study was selected as it offers a good scenario where one can observe the intersection between globalization, privatization, inequality and marginalization. Globalization and privatization are frequently discussed in education and are considered part of the forces driving current educational reforms all over the world (Ball, Junemann \& Santori, 2017; Robertson, \& Verger, 2012). Marginalization, however, is often considered either a consequence of globalization or the result of a more privatized education system. As such, marginalization can be a viewed as a creator of opportunities for privatization policies, for example, when the State is accused of failing to fulfill their mission of ensuring the provision of quality education for all (Klees, 2008; Lubienski, 2013). The tensions and controversies surrounding the privatization of education are present in an ongoing debate in Portugal regarding the contractualization of private school education services through 'association contracts', a form of educational provision common in several countries.

In 1980 Portugal created these contracts as a measure to prevent marginalization in areas of the country where the public offer was insufficient. The State, through these contracts, financed private schools where students could attend free of charge. Over time, however, the contracts moved away from their initial purpose and, nowadays, have become an ideological banner filled with diverse underlying assumptions on marginalization and education inequalities for those both for and against education privatization. The evolution of the conditions, justifications and practices for these contracts signal various conceptualizations of privatization, inequalities and marginalization.

Bearing in mind recent changes in the contractualization of educational services in Portugal, our paper aims to present an empirical study based on the analysis of online newspaper articles. We seek the arguments engaged in the public debate of 'association contracts.' Media coverage is perceived as a context in which "spaces of ideological struggle and spheres of public issues construction" are created (Porta \& Cianci, 2016, p. 41).

This paper is organized in three parts. The first part contextualizes the contractualization of educational services within the framework of the issues of governance and managerial reforms. We are committed to better understanding the broader processes involving the reorientation of the centrality of the State in the coordination of decisions, its collective action and the changes in the structural and procedural coordinates of (education) public administration (Antunes \& Viseu, 2017). Some of the consequences of the global movements towards managerialism and privatization are discussed, namely in terms of social justice, inequalities, segregation and marginalization. We highlight some features of the route taken to build the (as yet unfinished) Portuguese welfare State within a democracy; we also seek to examine the role of public policies with attention being given to certain traits and specificities of the public education system. We demonstrate why we consider the recent changes in the modes of contractualization with Portuguese private schools as constituting an interesting case on the issue of privatization in education. To this end, we present a three-decade history of association contracts between private schools and the Portuguese public system, highlighting significant moments and the meanings assigned to them.

\footnotetext{
${ }^{1}$ This research was supported by: a) Research Centre in Education /CIEd, Institute of Education, University of Minho, project UID/CED/01661/2019, through national funding from the Fundação para a Ciência e Tecnologia/FCT, MCTES-PT (Foundation for Science and Technology); b) UIDEF, Instituto de Educação, Universidade de Lisboa, through national funding from the Fundação para a Ciência e Tecnologia (Foundation for Science and Technology).
} 
The second part of the paper comprises the methodology and the results of the empirical study, which characterizes the media coverage debate on association contracts. The diversity of actors and arguments in the media coverage illustrates the relevance of the role taken on by the State in education provision and the tensions this generates with implications for educational equality.

Finally, we present some closing remarks on how this case can be a powerful indicator of the ongoing debate on education privatization, marginalization and social justice.

\section{Global Trends: Governance, Managerialism and Educational Inequalities}

We understand the processes of globalization as the intensification of world scale relationships, a set of heterogeneous, unequal and multidimensional, political, economic and cultural relationships that constitute a dynamic and peculiar structure for action (Giddens, 1992; Santos, 1997; Silva, 2017). Dale (2000) proposed the need to understand the relationships between the nature, the role and the place of the state in Westernized countries and the processes of globalization, while bearing in mind the direct, indirect and collateral "effects" of these dynamics. We underscore that the indirect effects of globalization on the governance of education include those consequences which, while not being specifically sought, nevertheless deeply alter education systems. These phenomena are rooted in some developments: (i) the "neoliberal constitutionalisation," for example, the setting up of the European Monetary System or the so-called new public management; (ii) the progressive broadening of the "network state" and the setting up of supranational political-economic bodies (at regional or other levels) such as the European Union or the World Trade Organization; and (iii) the globalization of production. These developments have had a powerful effect in changing both the pattern and the scale of governance, setting up a globally structured agenda for education (Dale, 2000; 2005, pp. 57-59; Robertson \& Dale, 2017).

The issue of governance and the reform of the managerial state is called upon to explain the creation of new modes of education provision (and other goods and services that realize social rights) and of socio-political coordination which entail the reconstruction, along new lines, of the centrality (to do what? on whose behalf and to further whose interests?) and the priorities of the state and other political bodies (the EU, for example; cf. Clarke \& Newman, 1997; Dale, 1997 , 2005). De-statization of the political regime phenomena, with the state assuming more of a coordinating role, has occurred alongside the development of the de-nationalization of the State, bringing about a change in scale, responsibilities, protagonists and, according to some, promoting a shift from government to governance (Jessop, 1995, 1997).

Due to this, the decision-making and the policy-building fields in education have been profoundly changed. On the one hand, they have become broader and more complex, including modalities and actors of the supranational (and subnational) space. On the other hand, those fields have been curtailed and emptied at the national level and, where some areas are concerned, even reactivated under a different status, notably as spheres for ratifying, developing or implementing options and decisions made at supranational levels. The aforementioned change therefore marks the emergence of a new order, which concerns the role of the state in the economy, in the production and distribution of social welfare, in its relationship with citizens, and in the coordination of activities and the agents involved in these areas (cf. Loncle, Amaral \& Dale, 2015, p. 11).

In education, as in other areas, a framework of unstable and loose boundaries has been progressively set up, "hybridized organizational forms, innovative governance arrangements" with the "involvement of a multiplicity of new providers of different kinds and the redistribution of power and responsibility" (Newman \& Clarke, 2012, p. 353; Junemann \& Ball, 2013, p. 423). Drawing up and developing education policies involves covering and coordinating diverse levels of 
political action, from local to supranational contexts in a multiregulation process (cf. Barroso, 2003; Oliveira, 2015).

Recent research shows that trajectories of privatization are visible with varying lengths and stages across the world, driven by policies that engage distinct protagonists and employ multiple strategies (Adrião, 2018; Peroni, Lima \& Kader, 2018; Verger, Moschetti \& Fontdevila, 2017). This visibility can be seen in several South American countries. For example, educational privatization has been analyzed as "part of the structural reform of the State in Chile" developing since the 1980s. We can also see a latent privatization in Uruguay since 2000 and an almost absent or refrained privatization respectively in Mexico and Bolivia (Verger, Moschetti \& Fontdevila, 2017). Other researchers discuss privatization (deregulation and marketization) "as part of a global development," constituting "three trends in attempts to reform Nordic educational systems" (Dovemark et al., 2018, p. 123).

The growing body of empirical research (see next section) documents the national mediation of a globally structured agenda for education (Dale, 2000). We suggest that the literature shows some of the ways by which the national realities - the specific actors and its interpretations, the available institutional resources and the particular history - mediate the agenda of the privatization of education, which is structured by the above mentioned global economic-political-cultural processes.

As Cardoso (2005) points out "one has to reflect on the interests that are being furthered and on the impact such interests have on the State-market-civil society relationship (...) and it has to be done in a context where the results of any initiative or development are evaluated by the manner in which the standards of equality and social justice are maintained in each location" (Cardoso, 2005, p. 113).

The question that remains is whether or not the concept of privatization encompasses the various frameworks and relations involving the public and private domains including the State, market agents, organized civil society or the third sector. This is complicated by the fact that there are no clear-cut definitive features or dividing lines separating the "public" from the "private" (Barroso, 2013) since they both depend on socio-political processes (Power \& Taylor, 2013) that include the recent expansion of privatization and the opening of spaces for the influence and benefit of private actors in education. Nevertheless, these relations, discussed by some authors as based on the concept of 'permeability', do take on observable patterns in accordance with "certain historic, socio-political and economic conditions": conceptions of the State and its role, functions and responsibilities to society and citizens, the pathways shaping certain policies, the dominant economic formulae and trends or the democratic interplay of political actors (Tripodi \& Sousa, 2018, p. 234). As suggested, the pattern of relationships between the "public" and the "private" can constitute a national mediation of a globally structured agenda, as the different trajectories of privatization seem to point out. Therefore, the processes analyzed in this text are concerned in several ways with the interactions between these factors and their dynamics, and how they can create contexts in which the observed trends materialize.

\section{The Transnationality of Managerialism in Public Schools}

The measures aimed at setting up education markets, guided by the managerialist agenda in education, are found at the transnational level and feature policy contamination and transfer effects (Dolowitz \& March, 2000). In particular, this seems to be the case in the importing of ideas, techniques and practices from the private to the public sector with the purpose of making the latter more competitive, business-like and commercially oriented to achieve a privatization lato sensu resulting "in new foundations of legitimization which public schools and universities have not only 
been subjected to but have themselves also actively sought, often in a clear and unconcealed manner that is forthrightly stated, discussed and publicized" (Lima, 2018, p. 142).

For decades the managerialist agenda has been promoted by supranational organizations such as the World Bank, the OECD and the EU, and the agenda is focused on reforming education through differing governance arrangements and policies, depending on specific national and institutional histories and resources. This interplay, between the large dissemination of certain trends and local, national, and historical specificities, constitutes the landmark of global reforms (Verger \& Romuald, 2015). For example, the school choice policy has been established in $75 \%$ of OECD members (Davis, 2013) and is consolidated in European countries including Belgium, Holland, Ireland and Spain (van Zanten \& Kosunen, 2013). In England, various waves of managerial reform have led to a growing privatization process with the "creation of schools as business units and the marketization of education in general" (Hall \& Gunter, 2015, p. 743). It is also seen in South America as Chile pioneered the "school voucher" system in the early 1980s, which led to substantial privatization of public education provision (Elacqua, 2012). In Brazil, despite educational reforms stemming from numerous policy guidelines since the 1990s, there has been, to a varying extent, "managerialist oriented reforms" (Oliveira et al, 2014, p. 531). One option that has marked Brazilian educational policy has been the constitution of partnerships between public sectors, namely at the municipal level, and the profitable private sector (Adrião, 2014).

The adoption of the managerialist canon in education as a transnational feature should be recognized as a sign of the reconfiguration of the traditional role of the state. Through this process, a reduction in bureaucratic regulation has taken place and market principles have gradually been introduced in public services. These reconfiguration processes can be traced back to a broader phenomenon of reforms that, under the influence of new public management, seek to reduce the alleged inefficient bureaucratic management of public goods by the authorities (Hood, 1991). In countries that traditionally lean more towards centralization (such as southern European countries), the solution consisted in bringing about privatization processes with the incentive of creating mechanisms that focused on the evaluation, accountability and targeting an end user or consumer (A. J. Afonso, 2012; N. Afonso, 2003; Lima, 2016).

Therefore, there is an identifiable trend in current public policies that is not confined to education, but is in fact visible in a wide range of sectors such as health, social security and justice that make up the welfare State. The fact that there is discourse favorable to managerialism at the transnational scale helps to understand a certain normalization of the discussion on the importance and supposed benefits of adopting market principles and endogenous privatization in public schools (Ball \& Youdell, 2008), or a variety of other forms to extend the scope of activity of providers and other private agents in education (Peroni, 2015).

Researchers have examined the global trend towards privatization of education from a human rights perspective, namely the fundamental human right to education. It has been discussed in terms of the tensions between "the "freedom dimension"" - choice by the parents and private actors - as well as by "the 'social equality' dimension" - the right to education - which is related to both "the principles of equality and non-discrimination," and also the entitlement to education and empowerment through education (Dorsi, 2016; Singh, 2015). Signaling "a failure of the state's obligation to protect the right to education" (Balsera, 2016, p. 984), this debate draws attention to the effects of privatization in education as it favors processes that concur with the marginalization of some social groups of students (Singh, 2015).

These trends are being researched and discussed on a worldwide level and questions have been raised regarding social justice, equality or marginalization outcomes, effects and consequences on educational, and learning participation, and life chances of underprivileged, disadvantaged or 
impoverished children and youth (Robertson \& Dale, 2013). Some of the research points out the fact that in Nordic countries, for example, social differentiation and segregation between schools and social groups grew at the same time as privatization, marketization and deregulation (Beach, 2017; Dovemark et al, 2018; Östh et al., 2013). Similarly, in Chile where measures to privatize public schooling have a longer history, recent studies have shown there are high levels of school segregation (Rambla et al., 2011) while selection mechanisms for the recruitment of elite students by private schools remain in place (Belleï, 2009).

\section{The State and Public Education Policies in Portugal: Between Democratization and Managerialism}

In the two decades following the 1974 revolution, which ended almost 50 years of dictatorship, public policies were crucial in upholding the democratization of education and social rights. This was a time of expansion for the education system and sought to ensure the consolidation and universal access to schooling, which, until then, had been limited. According to the 1976 Constitution of the Portuguese Republic, the state became responsible to create a universal public education system. However, public authorities had difficulties responding to the population's demand in the creation and opening of schools. This demand, as a consequence, created an opening for the expansion of private provision. The debate on the privatization of education had been touched upon in the 1980s as a result of the expansion of private higher education and the creation, through an initiative of the state using public funding, of a nationwide mainly private subsystem of vocational schools at the secondary education level, which had a high intake of students (Antunes, 2017; Seixas, 2000).

This led to the construction of what has been called a semi-welfare state (Santos, 1990). As a result, Portugal faced the simultaneous crisis and consolidation of mass schooling, which was a particularly prominent feature of the 1990s (Stoer, 1994). The semi or quasi-welfare state in Portugal has been characterized, among other conditions, by a low level of welfare expenses (Santos, 1999, p. 15) and a state bureaucracy that took a long time to realize that general access to social policy services and benefits is a "matter of right" (p. 27). More recently, some research has pointed out that Portugal is more aligned with other European countries in terms of socioeconomic variables including life expectancy, educational attainment, healthcare, poverty alleviation and unemployment protection, but "despite the slight decrease in inequality over time" it still "remains one of the most unequal countries in the EU and the OECD" (Alves, 2015, p. 20).

In fact, since the 1990s public policies have promoted a differentiated development in each of these sectors when it comes to private provision, to the role of the state in terms of education governance (funding, provision, regulation and ownership; Dale, 2005) and to framing the right to education and its democratization. It should be noted that the process of creating and consolidating the welfare state was simultaneously marked by the dynamics of Europeanization (Antunes, 2004; Dale, 2008; Nóvoa, 1998). Consequently, the public, political and academic debate on the redefinition of the role of the state as the main protagonist in the regulation, funding, ownership and provision of education grew in intensity and complexity. This was the initial part of a process that would be developed in the following decades. A process that would involve making choices about the organization of welfare services, which are connected to the managerial state reform (Clarke \& Newman, 1997).

If we observe the trend of education privatization that has developed in Portugal in recent years, we find what Verger, Moschetti \& Fontdevila (2017, p. 20) consider a low level of privatization (less than 15\% of students in private institutions) in basic education. In 2017, for example, $13.1 \%$ of Portuguese students were in private schools and there was a medium level of privatization $15 \%-30 \%$ of 
students in private institutions) in secondary schools and higher education. In the former, $21.3 \%$ of students attended private schools and $16.4 \%$ in the latter. A high level of privatization (30-65\% of students in private institutions) is found in pre-school education with $47.3 \%$ of children attending private institutions in Portugal (PORDATA, 2018).

Nevertheless, there is strong evidence of school and social segregation mechanisms in countries where the education system tends to be more centralized and the education markets are not yet consolidated. This appears to be the case in Portugal as it is one of the EU countries with higher inequality with regards to income distribution and education system inequalities (OECD, 2018).

In fact, despite the considerable progress made in the last few decades to expand and generalize access to the Portuguese education system, the fact remains that there has not been "a significant reduction in the different forms of social inequalities in terms of schooling" (Diogo \& Diogo, 2013, p. 1). This is confirmed in the 2017 publication of $O$ Atlas da Educação [The Education Atlas], which highlights inequalities in the Portuguese educational system with regards to dropout rates and school failure. Even though the authors concur that there are multiple factors, including poverty levels and parents' level of education, that contribute to this issue, they also underscore the importance of the distinctive features of local contexts that account for schooling inequality.

Understanding the state as a political relationship and as a field of political struggle (Peroni, 2011, p. 24; Santos, 1990) - where different interests, perspectives and courses of action oppose one another and must be negotiated - allows one to explain the central role it has played in two intertwined and parallel processes over the past forty years of democracy. On one hand, the state and its' public policies have been crucial in the expansion of the public education system and realizing the Portuguese people's constitutional right to education while, on the other hand, favoring and fostering privatization, marketization processes and actors that weaken and endanger this fundamental right.

The state's duplicity constitutes one of the underpinnings of the crisis and consolidation of the semiwelfare state and of mass schooling, as well as the mitigated educational neoliberalism in Portugal (Santos, 1990; Stoer \& Araújo, 1992). In addition, having an understanding of governance, the coordination of collective action and the matrix of social regulation, as a field of social practices, political struggle and action opens a channel for the questioning and examination of the most recent debate (and political confrontation) of association contracts between private schools and compulsory public education system, as well as the role played therein by the state.

\section{The Case of the Association Contracts with Private Schools}

As previously stated during the two decades following Portugal's 1974 revolution, the state had difficulties in responding to the people's educational demands, which allowed for the expansion of the private provision. These contracts with private schools served the purpose of ensuring an education provision in areas where there were public school shortages. This was one way to prevent inequality and marginalization of children living in areas where public schools did not exist or were insufficient. As such, contractualization with private schools occurred to ensure the children's fundamental right to education.

In more recent decades, the public education offer expanded with the creation of new schools. However, during this time some private school contracts continued to be renewed, which created an overlap of public and private schools in the same area, both using public funding.

In 2013, the government (supported by the right wing of the parliament) approved a new Statute for Private and Cooperative Education stating that contracts between the state and private schools could be made anywhere "even if there were public schools available" (Decree-Law n. ${ }^{\circ}$ 
152/2013). The policymakers' main argument to justify this measure was a cultural and ideological one with the goal of "guaranteeing families a right of choice" (Decree-Law n. ${ }^{\text {1 152/2013). This }}$ statute reinforced the idea - at least, in legal documents - that both the public and private provision could be equally supported by public funding, in order to enhance the choice of the families. Closely related with a supranational agenda, the government also claimed to be responding to the European Parliament and Council Directive 2006/123/EC, which established the framework to achieve an internal market without frontiers, with free movement of services. The government's perspective was that there should be no constraints placed on the choice between public or private schools. In a newspaper interview, the former Minister of Education stressed "the principle of competition" between public and private schools and even claimed that "the decision [of a certain school] is of the family and not the State" (Jornal de Notícias, 2013).

Besides the ideological justification for reinforcing private schools with public funding, we must also note that this measure was implemented during a time when many social policies, including education, suffered substantial financial cuts by the government. These cuts were a result of the intervention by the European Commission, the European Central Bank and the International Monetary Fund (also known as the troika of lenders' representatives), and formalized by the signing of the Memorandum of Understanding (MoU) of 17 May 2011, which registered the structural adjustment policies as a condition for the financial loan. Portugal had to make, in a very short time period, severe cuts in public expenditure. This meant reducing the scope, the resources, the capacity and the beneficiaries of public social policies in education, health and social security (see, for instance, EAPN, 2013; European Parliament, 2014; EPRS, 2013; Reis, 2014).

Some researchers argue that these alterations point to a neoliberal revolution since they led to a profound change in the position that education held in the Portuguese constitution and society (see Antunes, 2016). Even if the neoliberal government's 'coherent and global political project' had not been formulated as such in Portugal, nevertheless 'a neoliberal ideological agenda' was prevalent (Carmo et al., 2014, p. 170) and 'the Adjustment Program has served, above all, to protect and support an agenda of profound transformation [...] that, based on fundamentals of essentially ideological nature, very clearly transcends the idea of the simple financial contribution of the education sector to the balance of public finances' (Cantante et al, 2014, p. 76). At the time, the prime minister defended that it was cheaper to finance private schools, who get better results, using Sweden's independent schools as an example of good practice (TVI 24, 2016).

Consequently, public funding for private schools increased and. This change meant to create a redundant provision and actually worked as a financing instrument from the State for certain private education providers. Therefore, in addition to there being an ideological justification of public funding for private schools, it also appears that the economic crisis created new opportunities, which strengthened the privatization agenda.

In 2016, a new government in Portugal (this time supported by the left wing of the parliament) reviewed this process and determined that new association contracts could only exist in areas where the public education system offer was absent or insufficient. The arguments used, which will be further discussed, to justify this were culturally, ideologically and economically based, as the Minister of Education argued in the parliament:

"Being the Minister of Education in Portugal is a great responsibility: to reconcile public duty with the decision on how best to allocate, control and enhance taxpayers' resources for the purpose to which the people entrust their taxes: the public good. In this case, the public good in Education. (...) The respect for the State Budget requires us to use it as is necessary and not in a redundant way, not 
duplicating the bill paid by the taxpayer (...). But politically we will always defend the Public Schools that we want to improve" (Portuguese Parliament, 2016).

This excerpt shows how the political ('the public good') and economic concerns that arose from the crisis worked in combination with educational and social concerns or, more precisely, with the construction of the fundamental right to education and the construction of social-welfare.

Association contracts have been in place for over three decades and have dissociated themselves, to a significant extent, from their initial purpose. Over time, the contracts have been appropriated by many entities - the state and its agents, private for-profit and private non-profit education providers, students and their families - to further a variety of interests. In other words, over time the State elected to transform the association contracts, which were conceived as an instrument to realize the right to education, into a financing instrument - through paying private schools for pupils for whom public school was available - for private education providers.

On one hand, association contracts of schools combined with the state's financial support of public education system highlights the duplicitous role of the Portuguese state and its public policies in the domain of social welfare: at times promoting the construction of public structures for the provision of services that realize fundamental human rights; such as, education, health, social security; while, at other times, bolstering markets that create opportunities for private operators. On the other hand, this combination also illustrates how the same legal arrangement and public action instrument can, in different institutional and socio-political contexts and/or according with the democratic interplay of political actors (Tripodi \& Sousa, 2018, p. 234), be appropriated for diverse purposes, produce distinct material outcomes and take on conflicting political meanings.

\section{Media Coverage of School Association Contracts}

In early 2016, the changes affecting the criteria on which the association contracts would be established generated a public debate both for and against the political initiative. The debate was particularly lively in the newspapers, on television and on the radio with decision makers, citizen movements, teacher unions, public and private schools all advocating their position using multiple arguments that consisted of different underlying assumptions on privatization and educational inequalities.

Due to the widespread nature of this debate, it seemed like fertile empirical ground to analyze the processes of production and diffusion of education policies aimed at the privatization of education systems. Our study, therefore, falls within the scope of education policy studies, which uses media as an important object of inquiry and we believe it is warranted for two reasons.

First, we recognize the considerable influence of media on the public, through the processes of definition, framing and cultivation of the social and political agenda (Strömbäck, 2008). Thus, the media is not merely viewed as a channel of information exchange between policy decision-makers and their audiences, rather the media is perceived as an actor that both acts on and affects policy texts and processes through an active intermediary role (Baroutsis \& Lingard, 2017). Given the importance of mass-media in the construction of meanings and practices, particular attention will be paid to the debate and the arguments regarding the understanding of the role of the State and "the articulation of meanings associated with 'the public' and 'the private', since those definitions and distinctions, being temporary and unstable, depend on the policies, debates and actors that seek to influence them (Gerrard, Savage \& O'Connor, 2017, pp. 504-506; Klees \& Edwards Jr., 2015, p. 14). Furthermore, we are also aware that media actors play an important role on the "promotion of promarket education reforms" (Verger, Fontdevila \& Zancajo, 2016, p. 140). 
Second, for this study education policies are understood as being produced by a plurality of actors both public and private, including the media, operating within the State; or as partners or mediators at the local, national or supranational levels, with different conceptions, discourses and education agendas (Ball, 2016). As a consequence, and related to the fact that the media plays an important role in the struggle for social power (Lingard \& Rawolle, 2004), we perceive the media as policy co-producers. This results from the growing participation, interest and involvement of nongovernmental and private actors in educational policies (Verger, Lubienski, \& Steiner-Khamsi, 2016), which is understood to be a sign of the expansion of globalization and privatization trends.

\section{Methodology}

A documental corpus was created and comprised of 180 online newspaper articles on the changes in the contractualisation of educational services published in May 2016, the month in which the debate had the highest visibility. We chose to focus on online media considering that in Portugal digital platforms have been continually increasing, whereas the sales of print media have dropped sharply over the past 15 years: in 2000, 468,192 copies of newspapers and other periodicals were sold while in 2015 that figure fell to 234,102 (PORDATA, 2017).

The articles were gathered from four Portuguese online news outlets: Público, Diário de Notícias, and Observador and the radio station TSF Rádio Notícias. Diário de Notícias and TSF belong to Global Media, a group that includes other influential newspapers and print media. Público is the most widely read online newspaper in Portugal (ERC, 2015) and owned by the Portuguese multinational, Sonaecom, SGPS, SA. Observador is an online newspaper created with a clearly professed "rightwing" editorial line in 2014, and is not part of any large publishing group in Portugal. The criteria used to select these media outlets was due to their high viewership, their national scope and their non-specialized nature (PORDATA, 2017).

The treatment and analysis of the documental corpus followed a general qualitative content analysis, mainly concerned with answering the question: who said what and where? (Macnamara, 2005). The first phase $(w h o)$ consisted of extensive identification of the actors in the articles and a categorization according to their position (either for or against association contracts); we also took into account whether the actors were decision-makers, partners or mediators. The second phase (what) comprised of a comprehensive analysis of what was said in the articles. Therefore, a thematic categorization was used and we classified the arguments either in defense of or against association contracts. Through this process we inductively identified the main arguments put forward in the debate: legal, economic, ideological and educational. Once the categorization was complete, we proceeded to a descriptive statistic to identify the actors and arguments present in all of the analyzed media, as well as in each online media source (where), in an attempt to capture the existence of different journalistic treatments.

\section{Findings}

Analyzing the media coverage of association contracts enables one to discern certain structuring features of the debate, which may be summarized as follows: (i) the media participated in the debate and in policy building, considering the differences found in the reporting; (ii) the range of arguments put forward covered a limited socio-cognitive sphere underlining certain dominant trends: the judicialization of politics, the centrality of the economic/budgetary factor in legitimizing policy options, and the undervaluing of scientific knowledge of education and pedagogy; (iii) there are societal options regarding the relationship between the public and private domains in education 
which engages a high number and a wide variety of actors who have diverging proposals and interests.

\section{Media Participation in the Debate and Policy Building}

The analysis of the media coverage with regards to the policy measure in question revealed interesting differences in the reporting when it came to the actors who were heard. In the articles analyzed, it was ascertained that $50.1 \%$ of the actors were against restricting association contracts, thus obtaining higher media coverage. The data also showed that the private schools affected by the measure and their supporters were more prominently featured in the articles published in the Observador and Diário de Noticias when compared to the other media outlets. $56.3 \%$ of the articles published by Diário de Noticias and $55.8 \%$ by Observador focused on private schools and their supporters, whereas the figure in Público was $41.9 \%$.

This data points towards the mediatization of educational policy processes or, as stated by Lingard \& Rawolle (2004), frequently the media may both report on a crisis and create one. In fact, despite the public debate this issue generated the government did not reverse its decision and went on to apply the measures as announced. Therefore, it appears that rather than acting on policy processes and texts, this process points towards a controversy- generating mediatization.

\section{Legal, Economic and (Few) Educational Arguments}

The media coverage of school association contracts is frequently presented with references to legal and economic arguments, respectively in 31\% and 30\% of the articles, regardless of the actors who used them. The legal arguments focused particularly on the alleged legality or illegality of the change to the association contracts. For the president of the Association of Private and Cooperative Schools, these changes were unacceptable since "the current contracts could not be broken as they were multiannual" (Observador). Similarly, the Movement for the Defense of School Period (a social movement pro private schools) had sent 5000 letters to the Ministry of Education "appealing to the ministry to reverse the legislation that harms these schools (...) and to enforce the multiannual contracts" (idem).

Among those supporting the measure seeking to restrict the contracts to situations where there was a lack of public provision, the Secretary of Education (who works under the guidance of the Minister of Education) stated that the measure was warranted since it was meant to reinstate "the spirit underlying the introduction of these contracts in the 1980s, that is, (...) that the State is only obliged to fund new classes where there are no public schools or in cases where these are overcrowded" (TSF). The Prime Minister also clearly voiced his opinion on the issue: "Perhaps somebody was misled to believe that association contracts were no longer an exception and had become the rule, but that is not what is stated in the contracts, that is not what is laid down in the law and that is not what is in our Government Program" (TSF).

Regarding the issue of legal arguments, it should be mentioned that in order to challenge the government's decision several private schools affected by the restriction of the contracts took the matter to court. This occurred as the government concurrently requested the Prosecutor's General Office opinion on the legality of the measure. The increasing use of legal arguments noted in the media coverage demonstrates the processes of judicialization of education (Vallinder, 1994, p. 91; see also Konzen \& Cafrune, 2016; Santos, Marques \& Pedroso, 1995).

The common feature of the economic arguments put forth by both supporters and opponents of association contract restrictions was the alleged reduction in state expenditure. The Minister of the Presidency stated that "the only interest we want to further is the public interest, a good management of the taxpayers' money (Público). The former Prime Minister, who was the 
opposition leader in May 2016, asserted that "resorting to association contracts with private and cooperative education establishments does not cost either the State or the taxpayer more money" (Observador). Similarly, advocates for the Movement for the Defense of School Period maintained that "the cost represented [by private schools with association contracts] to the State Budget is much lower than that which the Ministry of Education has to pay for (...) in public schools" (Observador). Those who opposed the government decision also claimed that the State would have to bear new costs arising from the expected closure of private schools, dismissal of the teachers and the need to relocate students to other public schools.

The analysis of the arguments showed a limited expression of scientific and pedagogical knowledge as only $12 \%$ of the articles examined contained references made by either supporters or opponents of the association contracts. These arguments focused mainly on the idea that public or private schools, depending on who voiced the argument, had higher quality and, consequently, better academic results overall (Viseu, 2014). For example, the leader of one of the "right-wing" opposition parties stated that "it is not a clear-cut issue that a school that provides a good service, has good results, is preferred by the parents and is not an additional expense for the state should be sacrificed merely because there is a State public school nearby that must always be maintained" (Observador). However, the president of the National Association of Public School Principals highlighted the "quality of public schools' educational projects" and stated that in these schools were found "the better qualified and more experienced teachers" (Público). In addition, a public school teacher argued, without mentioning his sources, that "there are studies that show that public school students are better prepared [for further studies in higher education institutions]" (Observador).

This leads us to agree with the hypothesis put forward by Malin \& Lubienski (2015) who state that media impact is often disconnected from "educational expertise". The low number of education researchers, academics or experts who appear in the newspaper's articles analyzed signals the existence of a gap between education researchers and the rest of the public, something which has been previously reported as happening in various contexts (Nóvoa, 2015).

\section{Two Groups of Actors Involving Two Societal Options}

In the online newspaper articles, we identified 61 actors, both individual and collective. However, despite the considerable variety of actors, the results showed a significant dichotomization of the debate and two groups became easily discernible: those against restricting and those in favor of restricting the association contracts.

Naturally, among those against restricting the contracts are the private schools affected by the decision. Their views were voiced by many: teachers, directors, parents, associations representing the sector such as the Association of Private and Cooperative Schools, representatives of the Catholic Church and by parliamentary opposition parties. Among those in favor of restricting the contracts included members of the government, namely the Prime Minister, the Minister of Education and the Secretary of Education, as well as the federation of teachers' unions (FENPROF) and political parties supporting the government in parliament (the so-called "left-wing" of parliament).

The identification of these two groups, for and against association contracts, is a sign of the dichotomization between private and public education that remains in place (Barroso, 2003) with an increased visibility of ideological arguments. In fact, media coverage revealed that this debate went beyond the issue of association contracts and into a discussion on the role of the State in the provision of education (and of social welfare). The intensity of the debate between the two opposing sides was visible by the three collective actors that surfaced and/or gained more prominence during the course of this debate and policy process: the Movement for the Defense of School Period and the Movement of Schools with Contractualized Schooling (set up in 2011) brought together actors 
(students, parents, teachers, non-teaching staff, local government officials and formal as well as informal associations) who voiced their support for the private schools with association contracts. The Movement for the Defense of Public School is comprised of public school basic education, secondary education teachers and directors, higher education teachers, parents, local government officials, members of parliament as well as musicians and artists who, acting in their individual capacity, signed and disseminated a manifesto defending public schools and the government's right to concentrate its administration's education financial resources on them.

The discourse from private schools and their supporters clearly favored school choice freedom, with the state assuming a regulatory function. In the words of one mother, "I want to be able to choose the education project that will frame my children's education and I want to be able to have the freedom to do it. There is a school (...) that can do exactly that and has been sentenced to death because of ideological prejudice" (TSF). A Social Democratic Party (PSD) member of parliament stated that the measure sought to "make the State practically the sole education provider, eliminating pluralism, healthy competition between education projects and forgetting the fact that public education and public provision do not necessarily entail public management" (Público). Regarding this issue, representatives from the Catholic Church held a similar view declaring its "support for every initiative that (...) defends parents' freedom to choose the schools and education projects they wish for their children" (Diário de Noticias). The president of the Association of Catholic Schools also considered the measure to be not only an "attack on freedom of choice", but also an "attack on the Catholic Church" (idem).

Meanwhile among those who supported restricting the provision of private education services contracts, it was the Prime Minister who delivered what was perhaps the most emblematic message stating: "we must concentrate resources on defending public schools, [which] belongs to all of us, which ensures equal opportunities for all" (TSF). Likewise, a member of parliament from the Socialist Party (PS) stated that "the association contracts were never instruments for the promotion of freedom of choice" adding that "the concept of freedom of choice which the right believes in (...) would culminate in the segregation of education between the rich and the poor" (Público). Furthermore, a press release issued by the Movement for the Defense of Public School highlighted "at a time as important for education as this one, it is even more important to uphold Public School and simultaneously reject the idea that public and private can be one and the same" (TSF).

From these extracts one is able to ascertain that on this point the debate went more in-depth when it came to the role of the state and on other social welfare options, which has remained at the center of policy trends during the last few decades, including our more recent past. As underscored in a recent analysis of the Portuguese socio-political conjuncture: "One of the most symbolic measures that the PS government implemented was the reduction in financial support granted to private schools. This was an issue that mobilized civil society, with huge demonstrations organized by those both defending the private system of education and those supporting the State school" (Lisi, 2016, p. 15). Despite differences in content and intensity any given category of argument used clarifies, at this particular historic juncture in Portuguese society, the meanings assigned to public when it comes to its relation with the actions of the state and a fundamental right, such as education. The debate enabled one to capture the confrontation of conflicting views by revealing perspectives based on the blurring of boundaries between the public and private domains involving the privatization of public resources, as well as the organization of the provision in market terms when having competition and consumer choice at its center. This clearly contrasts the perspective which considers that the public good is materialized by the state taking on the responsibility of setting up structures, managing resources and regulating socio-educational relationships within a decommodification framework. 


\section{Final Remarks: A Specific Portuguese Episode of Privatization, Inequality, and Right to Education}

The study sought to examine the controversy generated by the political decision to limit private school association contracts within the Portuguese public education system in 2016. This 'empirical window' called upon global trends that has challenged the governance of education for decades with managerial reforms, privatization, persistent inequalities and varying degrees of marginalization while expanding a universal and stratified education system.

We argue that from the mid-1990s onwards, and particularly in the last decade in Portugal, public education policies have been developed within the framework of a national political agenda, structured by global processes mediated by Europeanization. This agenda has highlighted the ambivalence of the state in public education, for example, by reinforcing association contracts in 2013 or later, in 2016, by reducing the number of these contracts.

By the first option, the Portuguese public policies have contributed to the global trends of privatization, concurrence and managerialism in education. By the second option, the ideological arguments present in media coverage show the concerns with public school system and the fundamental right to education. There was a concern to avoid the risk of undermining the centrality and the status of public provision and the de-commodified access to education. Therefore, both agendas where supported by different conceptions about the state role and privatization on education system, constituting equally political options of a global reach. Nevertheless, both where connected with the economic concerns: the first committed to comply with the structural adjustment policies of the "troika" intervention, with substantial cuts on public spending, arguing that financing private school, would reduce costs for the state; the second arguing that public resources should be applied in the public education, avoiding waste and/or double funding.

In conclusion, we would like to present two closing remarks. The first pertains to the nature of the empirical work. The analysis of media coverage of school association contracts appears to lend itself well to the observation of the various actors involved in the public debate. These actors put forth a range of arguments and produced several narratives on the role of the state in education. One of the actors was the media itself, who through the various approaches in reporting gave more or less prominence to certain actors and their arguments. Thereby, we contend that the media may qualify as a co-producer of education policies. The visibility of private schools and their supporters in certain media outlets, namely the online journal Observador with its' explicit "right-wing" editorial line, can be seen as a signal of the important role that some media are playing in the privatization agenda.

The second remark is in regards to the importance of - and the strife provoked by - the responsibility of the state in (compulsory) education provision, which can be interpreted by the magnitude of the debate and the organization by the conflicting interests that materialized during the debate. The fragile Portuguese semi-welfare state contributed to the global dissemination of managerial and privatization options in education, particularly during the years of the so-called structural adjustment policies. More recently the state, through a conflict-ridden movement of divergence and local specification, has accepted its obligation of protecting the people's right to education by reinforcing the public education system and limiting the private school association contracts. The contracts, initially aimed precisely at reducing inequalities and marginalization in the education system, however, eventually morphed, as our empirical study showed, into a banner for or against the privatization of education.

As previously argued, the debate on social movements' formation and the expression of private school association contracts in Portugal suggests that the funding of education is a major and 
divisive political issue with underlying and conflicting societal projects being contradictorily equated with social justice, inequality or marginalization. The particular case we studied is interesting in that it clearly illustrates the ambivalent role of the Portuguese state in building the public system of education, as well as highlighting the complexity and ambiguity of the public debate on education.

\section{References}

Adhikary, R. W., Lingard, B., \& Hardy, I. (2018). A critical examination of Teach for Bangladesh's Facebook page: 'Social-mediatisation' of global education reforms in the 'post-truth' era. Journal of Education Policy, 33(5), 632-661. https://doi.org/10.1080/02680939.2018.1445294

Adrião, T. (2014). Escolas charters nos EUA: Contradições de uma tendência proposta para o Brasil e suas implicações para a oferta da educação pública. Educação e Filosofia, 28(1), 263-282.

Adrião, T. (2018). Dimensões e formas da privatização da educação no Brasil: Caracterização a partir de mapeamento de produções nacionais e internacionais. Currículo sem Fronteiras, 18 (1), 8-28.

Afonso, A. J. (2012). Para uma concetualização alternativa de accountability em educação. Educação \& Sociedade, 33(119), 471-484. http://dx.doi.org/10.1590/S0101-73302012000200008

Afonso, N. (2003). A regulação da educação na Europa: Do Estado educador ao controlo social da escola pública. In: J. Barroso (Org.). A escola pública - regulação, desregulação privatização (pp. 4978). Porto: Asa.

Alves, S. (2015). Welfare state changes and outcomes-The cases of Portugal and Denmark from a comparative perspective. Social Policy \& Administration, 49(1), 1-23.

Antunes, F. (2004). Politicas educativas nacionais e globalização. novas instituições e processos educativos. $O$ subsistema de Escolas Profissionais em Portugal (1987-1998). Braga: Universidade do Minho.

Antunes, F. (2016). Economising education: From the silent revolution to rethinking education. A new moment of Europeanisation of education? European Educational Research Journal, 15(4), 410-427. https://doi.org/10.1177/1474904116641696

Antunes, F. (2017). Uma trajetória singular? Apontamentos sobre europeização, privatização e especificidades do ensino superior português. Revista Eletrônica de Educação, 11(1), 165-184. http:/ /dx.doi.org/10.14244/198271992096

Antunes, F., \& Viseu, S. (2017). A cobertura mediática (midiática) do debate público. Governação e privatização da educação em Portugal. Revista Retratos da Escola, 11(21), 501-523. http://dx.doi.org/10.22420/rde.v11i21.789

Ball, S. J. (2016). Following policy: Networks, network ethnography and education policy mobilities. Journal of Education Policy, 31(5), 549-566. https://doi.org/10.1080/02680939.2015.1122232

Ball, S. J., \& Youdell, D. (2008). Hidden privatisation in public education. Brussels: Education International.

Ball, S. J., Junemann, C., \& Santori, D. (2017). Edu. net: Globalisation and education policy mobility. London: Routledge.

Balsera, M. R. (2016). How do States regulate the role of private actors in education? General trends in national education laws. Compare: A Journal of Comparative and International Education, 46(6), 976-1000. https://doi.org/10.1080/03057925.2016.1207939

Baroutsis, A., \& Lingard, B. (2017). Counting and comparing school performance: an analysis of media coverage of PISA in Australia, 2000-2014. Journal of Education Policy, 32(4), 432-449. https://doi.org/10.1080/02680939.2016.1252856

Barroso, J., \& Viseu, S. (2006). De la régulation par l'offre scolaire à la régulation par la demande: le cas de Lisbonne. Revue Française de Pédagogie, 156, 51-61. 
Barroso, J. (2003). A escola pública: Regulação, desregulação, privatização. Oporto: Edições ASA.

Barroso, J. (2013). Autonomia das escolas: Entre público e privado. In V. M. V. Peroni (org), Redefinições das fronteiras entre o público e o privado: implicações para a democratização da educação (pp. 4857). Brasília: Liber Livro.

Beach, D. (2017). Whose justice is this! Capitalism, class and education justice and inclusion in the Nordic countries: Race, space and class history. Educational Review, 69(5), 620-637. https://doi.org/10.1080/00131911.2017.1288609

Belleï, C. (2009). Does lengthening the school day increase students' academic achievement? Results from a natural experiment in Chile. Economics of Education Review, 28(5), 629-640. https://doi.org/10.1016/j.econedurev.2009.01.008

Cantante, F., Serra, N., Abrantes, P., \& Carmo, R. (2014). Educação: Os avanços num caminho ainda a percorrer. In: R. Carmo \& A. Barata (Eds), Estado social: De todos para todos (pp. 51-89). Lisbon: Tinta da China.

Cardoso, C. (2005). O público no privado e o privado no público em Portugal e na Inglaterra. In Th. Adrião \& V. Peroni (Eds), O público e o privado na educação. Interfaces entre Estado e sociedade (pp. 81-117). São Paulo: Xamã.

Carmo, R., Ferrão, J., \& Malheiros, J. (2014). Geografias do Estado social. Reorganização territorial, habitação e urbanismo. In: R. Carmo \& A. Barata (Eds), Estado social: De todos para todos (pp. 167-200). Lisbon: Tinta da China.

Clarke, J., \& Newman, J. (1997). The managerial State. London: Sage.

Dale, R. (1997). The State and the governance of education: An analysis of the restructuring of the State-education relationship. In A. H. Halsey, H. Lauder, Ph. Brown \& A. Wells (Eds.), Education - culture, economy and society (pp. 273-282). New York: Oxford University Press.

Dale, R. (2005). A globalização e a reavaliação da governação educacional. Um caso de ectopia sociológica. In A. Teodoro \& C. A. Torres (Eds.) Educação crítica e utopia. Perspectivas para o século XXI (pp. 53-69). Oporto: Afrontamento.

Dale, R. (2008). Construir a Europa através de um Espaço Europeu de Educação. Revista Lusófona de Educação, 11, 13-30.

Davis, J. (2013). School Choice in the States: A Policy Landscape. Council of Chief State School Officers. http:/ / files.eric.ed.gov/fulltext/ED542701.pdf (Access December 2015).

Diogo, A. \& Diogo, F. (2013) (oOgs.). Desigualdades no sistema educativo percursos, transições e contextos. Lisboa: Mundos Sociais.

Directive 2006/123/EC of the European Parliament and of the Council (2006).

Dolowitz, D. P., \& Marsh, D. (2000). Learning from abroad: The role of policy transfer in contemporary policy-making. Governance, 13(1), 5-23.

Dorsi, D. (2016). Non-State actors' involvement in education and human rights: a tension between the social equality and freedom dimensions of the right to education. Compare: A Journal of Comparative and International Education, 46(6), 976-1000. https://doi.org/10.1080/03057925.2016.1207939

Dovemark, M., Kosunen, S., Kauko, J., Magnúsdóttir, B., Hansen P., \& Rasmussen, P. (2018). Deregulation, privatisation and marketisation of Nordic comprehensive education: Social changes reflected in schooling. Education Inquiry, 9(1), 122-141.

https://doi.org/10.1080/20004508.2018.1429768

Easton, D. (1992). Categorías para el análisis sistémico de la política. In A. Batlle (Ed.), Diez textos básicos en ciencia política (pp. 221-230). Barcelona: Editora Ariel. 
Elacqua, G. (2012). The impact of school choice and public policy on segregation: Evidence from Chile. International Journal of Educational Development, 32(3), 444-453. https:/ / doi.org/10.1016/j.ijedudev.2011.08.003

ERC. (2015). Caracterização dos principais grupos económicos da comunicação social. $<$ http://www.erc.pt/pt/estudos-e-publicacoes/estudos/caracterizacao-dos-principais-gruposeconomicos-da-comunicacao-social>. (Access September 2017).

European Anti-Poverty Network. (2013). Lifeboat or life sentence? The Troika and emergency assistance programmes and their impact on poverty and social exclusion. http://www.eapn.eu/en/news-and-publications/publications/eapn-position-papers-andreports/new-eapn-report-on-troika-programmes-and-impact-lifeboat-or-life-sentence.

European Parliament (2014) European Parliament resolution of 13 March 2014 on the enquiry on the role and operations of the Troike (ECB, Commission and IMF) with regard to the euro area programme countries. http:/ / www.europarl.europa.eu/sides/getDoc.do?type=TA\&language $=$ EN\&reference $=$ P7TA-2014-0239.

European Parliamentary Research Service. (2013). Social dimension of austerity measures. Cases of four EU countries in receipt of financial assistance. Briefing European Parliamentary Research Service, 10/12/2013. http://epthinktank.eu/tag/eprs-briefings/page/6/.

Gerrard, J., Savage, G. C., \& O’Connor, K. (2017). Searching for the public: School funding and shifting meanings of 'the public' in Australian education. Journal of Education Policy, 32(4), 503519. https://doi.org/10.1080/02680939.2016.1274787

Giddens, A. (1992). As consequências da modernidade. Oeiras: Celta.

Hall, D., \& Gunter, H. M. (2015). A nova gestão pública na Inglaterra: A permanente instabilidade da reforma neoliberal. Educação \& Sociedade, 36(132), 743-758. http://dx.doi.org/10.1590/ES0101-73302015152454

Hood, C. (1991). A public management for all seasons? Public Administration, 69(1), 3-19. http://dx.doi.org/10.1111/j.1467-9299.1991.tb00779.x

Jessop, B. (1995). The regulation approach, governance and post-Fordism: Alternative perspectives on economic and political change? International Journal of Human Resource Management, 24(3), 307-333. https://doi.org/10.1080/03085149500000013

Jessop, B. (1997). The future of the national: Erosion or reorganization? General reflections on the Western European case. Dept. of Sociology, University of Lancaster.

Jornal de Notícias. (2013). Ministério da Educação não exclui criação do cheque ensino [Ministry of Education does not exclude school vouchers].

$<$ https://www.jn.pt/sociedade/educacao/interior/ministerio-da-educacao-nao-exclui-criacaodo-cheque-ensino--3405967.html>

Junemann, C. \& Ball, S. (2013). ARK and the revolution of State education in England. Education Inquiry, 4, 423-441. http://dx.doi.org/10.3402/edui.v4i3.22611

Klees, S. J., \& Edwards Jr., D. B. (2015). Privatização da educação, experiências dos Estados Unidos e outros países. Revista Brasileira de Educação, 20(60), 11-30. http://dx.doi.org/10.1590/S141324782015206002

Konzen, L. P., \& Cafrune, M. (2016). A judicialização dos conflitos urbano-ambientais na América Latina. Revista Direito e Práxis, 7(14). http:/ /dx.doi.org/10.12957/dep.2016.22967

Lima, L. C. (2016). Evaluación hiperburocrática. Profesorado. Revista de Currículum y Formación de Profesorado, 20(3), 87-118.

Lima, L. C. (2018). Privatização lato sensu e impregnação empresarial na gestão da educação pública. Currículo sem Fronteiras, 18(1), 129-144. 
Lingard, B., \& Rawolle, S. (2004). Mediatizing educational policy: The journalistic field, science policy, and cross-field effects. Journal of Education Policy, 19(3), 361-380.

http://dx.doi.org/10.1080/0268093042000207665

Lisi, M. (2016): U-Turn: The Portuguese Radical Left from marginality to government support. South European Society and Politics, 21(4), 541-560. http://dx.doi.org/10.1080/13608746.2016.1225331

Loncle, P., do Amaral, M. P., \& Dale, R. (2015). Introduction. Shaping the futures of young Europeans: Education governance in eight European countries. In M. Parreira do Amaral, R. Dale \& P. Loncle (Eds.). Shaping the Futures of Young Europeans: Education Governance in Eight European Countries (pp. 7-22). Oxford: Symposium Books Ltd.

Macnamara, J. R. (2005). Media content analysis: Its uses, benefits and best practice methodology. Asia Pacific Public Relations Journal 6(1), 1-34.

Malin, J. R., \& Lubienski, C. (2015). Educational expertise, advocacy, and media influence. Education Policy Analysis Archives/Archivos Analíticos de Politicas Educativas, 23(6). http://dx.doi.org/10.14507/epaa.v23.1706

Newman, J., \& Clarke, J. (2012). Gerencialismo. Educação \& Realidade, 37(2), 353-381. http://dx.doi.org/10.1590/S2175-62362012000200003

Nóvoa, A. (1998). Histoire \& comparaison: Essais sur l' éducation. Lisbon: Educa.

Nóvoa, A. (2015). Em busca da Liberdade nas universidades: Para que serve a investigação em Educação?. Revista Lusófona de Educaşão, 28, 11-21

OECD. (2018). A broken social elevator? How to promote social mobility. Paris: OECD. https://doi.org/10.1787/9789264301085-en

Oliveira, D. (2015). Nova gestão pública e governos democrático-populares: Contradições entre a busca da eficiência e a ampliação do direito à educação. Educação \& Sociedade, 36(132), 625-646. http://dx.doi.org/10.1590/ES0101-73302015152440

Oliveira, D., Vieira, L. \& Augusto, M. H. (2014). Políticas de responsabilização e gestão escolar na educação básica brasileira. Linhas Críticas, 20(43), 529-548.

Östh, J., Andersson, E., \& Malmberg, B. (2013). School choice and increasing performance difference: A counterfactual approach. Urban Studies, 50(2), 407-425. https://doi.org/10.1177/0042098012452322

Peroni, V. (2011). Público/privado na educação especial em tempos de redefinições no papel do Estado. In M. Kassar (Org.), Diálogos com a diversidade: sentidos da inclusão (pp. 39-60). Campinas: Mercado de Letras.

Peroni, V. (2015). Implicações da relação público-privada para a democratização da educação no Brasil. In: V. Peroni (Org.). Diálogos sobre as redefinições no papel do Estado e nas fronteiras entre o público e o privado na educação (pp. 15-34). São Leopoldo: Oikos.

Peroni, V. M. V., Lima, P. V. de, \& Kader, C. R. (Orgs.) (2018). Redefinições das fronteiras entre o público e o privado. Implicações para a democratização da educação. São Leopoldo: Oikos.

PORDATA. (2017). Jornais e outras publicações periódicas. < https://www.pordata.pt/>.

Porta, E., \& Cianci, M. (2016). Médiatisation du processus de privatisation de - et dans - l'éducation en Amérique Latine et Caraïbes: Une étude du discours des médias. Educação \& Sociedade, 37 (134), 35-54. https://dx.doi.org/10.1590/ES0101-73302016157550

Portuguese Parliament. (2016). Speech by the Minister of Education about association contracts in education, May 7, 2016.

Power, S., \& Taylor, C. (2013). Social justice and education in the public and private spheres, Oxford Review of Education, 39(4), 464-479. https://dx.doi.org/10.1080/03054985.2013.821854

Rambla, X., Valiente, Ó., \& Frías, C. (2011). The politics of school choice in two countries with large private-dependent sectors (Spain and Chile): family strategies, collective action and 
lobbying. Journal of Education Policy, 26(3), 431-447. https:/ / doi.org/10.1080/02680939.2010.540675

Reis, J. (Coord.). (2014). A economia política do retrocesso. Crise, causas e objectivos. Coimbra: Almedina/CES.

Robertson, S., \& Dale, R. (2013). The social justice implications of privatisation in education governance frameworks: A relational account, Oxford Review of Education, 39(4), 426-445. https://dx.doi.org/ 10.1080/03054985.2013.820465.

Robertson, S., \& Dale, R. (2017). Comparando políticas em um mundo em globalização: Reflexões metodológicas. Educação \& Realidade, 42(3), 859-876. https://dx.doi.org/10.1590/2175623670056.

Sá, V., \& Antunes, F. (2013). Arguments' for school choice: A case study with Portuguese parents. Reis. Revista Española de Investigaciones Sociológicas, 143, 93 - 111.

Santos, B. de S. (1990). O estado e a sociedade em Portugal (1974-1988). Porto: Afrontamento.

Santos, B. de S. (1997). Por uma concepção multicultural de direitos humanos. Revista Crítica de Ciências Sociais, 48, 11-32.

Santos, B. de S. (1999). The welfare state in Portugal. Between conflicting globalizations. Oficina do CES(140). Coimbra: CES.

Santos, B. S., Marques, M., \& Pedroso, J. (1995). Los tribunales en la sociedades contemporaneas. Pensamiento Jurídico, 4, 5-38.

Seixas, A. M. (2000). O ensino superior privado em Portugal: Políticas e discursos. Revista Portuguesa de Educaşão, 13(2), 53-79.

Silva, A. S. (2017). Agir na globalização: Condições e orientações da ação coletiva. Sociologia, Problemas e Práticas, (84), 121-138. https://dx.doi.org/10.7458/SPP2017849992.

Singh, K. (2015). Safeguarding education as public good and regulating private providers. Social Change, 45(2), 308-323.

Stoer, S., \& Araújo, H. C. (1992). Escola e aprendizagem para o trabalbo num país da (semi) periferia europeia. Lisboa: Escher.

Stoer, S. (1994). O estado e as políticas educativas: Uma proposta de mandato renovado para a escola democrática. Revista Crítica de Ciências Sociais, 41, 3-33.

Strömbäck, J. (2008). Four phases of mediatization: An analysis of the mediatization of politics. The International Journal of Press/Politics, 13(3), 228-246.

TVI 24. (2016). Contratos de associação: Passos dir que discussão é "retrógrada" [Association contracts: Passos says discussion is "retrograde"]. <https://tvi24.iol.pt/politica/passoscoelho/contratos-de-associacao-passos-diz-que-discussao-e-retrograda $>$

Tripodi, Z. F.. \& Sousa, S. Z. (2018). Do governo à governança: Permeabilidade do Estado a lógicas privatizantes na educação. Cadernos de Pesquisa, 48(167), 228-253. http://dx.doi.org/10.1590/198053144800.

Vallinder, T. (1994). The judicialization of politics-A world-wide phenomenon: Introduction. International Political Science Review, 91-99.

Van Zanten, A., Kosunen, S. (2013). School choice research in five European countries: The circulation of Stephen Ball's concepts and interpretations. London Review of Education, 11(3), 239-255. https://doi.org/10.1080/14748460.2013.840984.

Verger, A., \& Normand, R. (2015). Nueva gestión pública y educación: Elementos teóricos y conceptuales para el estudio de un modelo de reforma educativa global. Educação \& Sociedade, 36(132), 599-622. https://dx.doi.org/10.1590/ES0101-73302015152799.

Verger, A., Lubienski, C., \& Steiner-Khamsi, G. (2016). The emergence and structuring of the global education industry: Towards an analytical framework. In A. Verger, C. Lubienski, \& G. 
Steiner-Khamsi (eds). World yearbook of education 2016: The global education industry (pp. 23-44). New York: Routledge.

Verger, A., Fontdevila, C., \& Zancajo, A. (2016). The privatization of education: A political economy of global education reform. New York: Teachers College Press.

Verger, A., Moschetti, M. \& Fontdevila, C. (2017). La privatización educativa en América Latina: Una cartografía de políticas, tendencias y trayectorias. Barcelona: Universitat Autònoma de Barcelona.

Viseu, S. (2014). Revisitando o debate sobre o público e o privado em educação: da dicotomia à complexidade das políticas públicas. Ensaio: Avaliação e Políticas Públicas em Educação, 22(85), 899-916. http:/ /dx.doi.org/10.1590/S0104-40362014000400003

\section{About the Authors}

\section{Fátima Antunes}

Centro de Investigação em Educação (CIEd)/Research Centre in Education

Universidade do Minho/University of Minho

fantunes@ie.uminho.pt

http://orcid.org/0000-0001-9045-7757

https://www.researchgate.net/profile/Fatima Antunes

Fátima Antunes is a researcher at the Center of Research in Education (CIEd) and Associate

Professor of the Department of Social Sciences of Education at the Institute of Education of the University of Minho (Portugal). Research interests include: education policies, globalization and the European Union; education governance, public policies and managerialism; education, democracy, differences and social justice; secondary and vocational education policies; and publishes regularly in Anglophone and Lusophone journals and books.

\section{Sofia Viseu}

UIDEF, Instituto de Educação, Universidade de Lisboa sviseu@ie.ulisboa.pt http://orcid.org/0000-0002-0059-9717

Sofia Viseu is an Assistant Professor at the Institute of Education of the University of Lisbon (Portugal). Her research interests include: educational policy, educational governance, policy network, privatization in education. Her recent work as a focus on the role of new intermediary actors in the fabrication of education policies.

\section{About the Guest Editors}

\section{Brent Edwards Jr.}

University of Hawaíi at Mānoa

brent.edwards@,hawaii.edu

http://orcid.org/0000-0003-3955-9525

D. Brent Edwards Jr. is an associate professor of theory and methodology in the study of education at the University of Hawai'i at Mānoa. He has more than 10years of experience as an educator, researcher, and scholar of education policy. In his scholarship, he applies political economy perspectives to (a) the examination of the global governance of education and (b) the origins, spread and effects of global education policies. In particular, Brent focuses on the ways that a range of international organizations affect the politics and processes of policymaking and policy 
implementation. Geographically, these areas of focus have led to research projects on education in many countries across Latin America, Southeast Asia, and Africa. His recent books include The Trajectory of Global Education Policy: Community-based Management in El Salvador and the Global Reform Agenda and Global Education Policy, Impact Evaluations, and Alternatives: The Political Economy of Knowledge Production (both with Palgrave MacMillan). He also has a forthcoming co-edited special issue of Educational Policy entitled "School choice policy and politics around the globe: Sociological contributions."

\section{Alexander Means}

University of Hawaíi at Mānoa

meansaj@,hawaii.edu

Alexander Means is an assistant professor of educational policy with global perspectives in the Department of Educational Foundations, University of Hawai'i at Mānoa. He is the author most recently of Learning to Save the Future: Rethinking Education and Work in the Era of Digital Capitalism (Routledge, 2018); Educational Commons in Theory and Practice: Global Pedagogy and Politics (Palgrave, 2017); and The Wiley Handbook of Global Education Reform (Wiley-Blackwell, 2018). His research examines educational policy and organization in relation to political, economic, cultural, technological, and social change.

\section{Special Issue}

Globalization, Privatization, Marginalization:

Assessing Connections in/through Education

\section{education policy analysis archives}

Volume 27 Number 125 October 14, 2019

ISSN 1068-2341

\section{(c) (1) (2)}

Readers are free to copy, display, distribute, and adapt this article, as long as the work is attributed to the author(s) and Education Policy Analysis Archives, the changes are identified, and the same license applies to the derivative work. More details of this Creative Commons license are available at https://creativecommons.org/licenses/by-sa/2.0/. EPAA is published by the Mary Lou Fulton Institute and Graduate School of Education at Arizona State University Articles are indexed in CIRC (Clasificación Integrada de Revistas Científicas, Spain), DIALNET (Spain), Directory of Open Access Journals, EBSCO Education Research Complete, ERIC, Education Full Text (H.W. Wilson), QUALIS A1 (Brazil), SCImago Journal Rank, SCOPUS, SOCOLAR (China).

Please send errata notes to Audrey Amrein-Beardsley at audrey.beardsley@asu.edu

Join EPAA's Facebook community at https://www.facebook.com/EPAAAAPE and Twitter feed@epaa_aape. 


\section{education policy analysis archives editorial board}

Lead Editor: Audrey Amrein-Beardsley (Arizona State University)

Editor Consultor: Gustavo E. Fischman (Arizona State University)

Associate Editors: Melanie Bertrand, David Carlson, Lauren Harris, Eugene Judson, Mirka Koro-Ljungberg, Daniel Liou, Scott Marley, Molly Ott, Iveta Silova (Arizona State University)

Cristina Alfaro

San Diego State University

Gary Anderson

New York University

Michael W. Apple

University of Wisconsin, Madison

Jeff Bale

University of Toronto, Canada

Aaron Bevanot SUNY Albany

David C. Berliner

Arizona State University

Henry Braun Boston College

\section{Casey Cobb}

University of Connecticut

Arnold Danzig

San Jose State University

Linda Darling-Hammond

Stanford University

Elizabeth H. DeBray

University of Georgia

David E. DeMatthews

University of Texas at Austin

Chad d'Entremont Rennie Center

for Education Research \& Policy

John Diamond

University of Wisconsin, Madison

Matthew Di Carlo

Albert Shanker Institute

Sherman Dorn

Arizona State University

Michael J. Dumas

University of California, Berkeley

Kathy Escamilla

University ofColorado, Boulder

Yariv Feniger Ben-Gurion

University of the Negev

Melissa Lynn Freeman

Adams State College

Rachael Gabriel

University of Connecticut
Amy Garrett Dikkers University

of North Carolina, Wilmington

Gene V Glass

Arizona State University

Ronald Glass University of

California, Santa Cruz

Jacob P. K. Gross

University of Louisville

Eric M. Haas WestEd

Julian Vasquez Heilig California

State University, Sacramento

Kimberly Kappler Hewitt

University of North Carolina

Greensboro

Aimee Howley Ohio University

Steve Klees University of Maryland

Jaekyung Lee SUNY Buffalo

Jessica Nina Lester

Indiana University

Amanda E. Lewis University of

Illinois, Chicago

Chad R. Lochmiller Indiana

University

Christopher Lubienski Indiana

University

Sarah Lubienski Indiana University

William J. Mathis

University of Colorado, Boulder

Michele S. Moses

University of Colorado, Boulder

Julianne Moss

Deakin University, Australia

Sharon Nichols

University of Texas, San Antonio

Eric Parsons

University of Missouri-Columbia

Amanda U. Potterton

University of Kentucky

Susan L. Robertson

Bristol University
Gloria M. Rodriguez

University of California, Davis

R. Anthony Rolle

University of Houston

A. G. Rud

Washington State University

Patricia Sánchez University of

University of Texas, San Antonio

Janelle Scott University of

California, Berkeley

Jack Schneider University of

Massachusetts Lowell

Noah Sobe Loyola University

Nelly P. Stromquist

University of Maryland

Benjamin Superfine

University of Illinois, Chicago

Adai Tefera

Virginia Commonwealth University

A. Chris Torres

Michigan State University

Tina Trujillo

University of California, Berkeley

Federico R. Waitoller

University of Illinois, Chicago

Larisa Warhol

University of Connecticut

John Weathers University of

Colorado, Colorado Springs

Kevin Welner

University of Colorado, Boulder

Terrence G. Wiley

Center for Applied Linguistics

John Willinsky Stanford University

Jennifer R. Wolgemuth

University of South Florida

Kyo Yamashiro

Claremont Graduate University

Miri Yemini

Tel Aviv University, Israel 


\section{archivos analíticos de políticas educativas consejo editorial}

Editor Consultor: Gustavo E. Fischman (Arizona State University)

Editores Asociados: Felicitas Acosta (Universidad Nacional de General Sarmiento, Argentina), Armando Alcántara Santuario (Universidad Nacional Autónoma de México), Ignacio Barrenechea, Jason Beech (Universidad de San Andrés), Angelica Buendia, (Metropolitan Autonomous University), Alejandra Falabella (Universidad Alberto Hurtado, Chile), Veronica Gottau (Universidad Torcuato Di Tella), Antonio Luzon, (Universidad de Granada), José Luis Ramírez, (Universidad de Sonora), Paula Razquin, Axel Rivas (Universidad de San Andrés), Maria Alejandra Tejada-Gómez (Pontificia Universidad Javeriana, Colombia)

Claudio Almonacid

Universidad Metropolitana de

Ciencias de la Educación, Chile

Miguel Ángel Arias Ortega

Universidad Autónoma de la

Ciudad de México

Xavier Besalú Costa

Universitat de Girona, España

Xavier Bonal Sarro Universidad

Autónoma de Barcelona, España

Antonio Bolívar Boitia

Universidad de Granada, España

José Joaquín Brunner

Universidad Diego Portales, Chile

Damián Canales Sánchez

Instituto Nacional para la

Evaluación de la Educación, México

Gabriela de la Cruz Flores

Universidad Nacional Autónoma de México

Marco Antonio Delgado Fuentes Universidad Iberoamericana, México

Inés Dussel, DIE-CINVESTAV, México

Pedro Flores Crespo Universidad Iberoamericana, México
Ana María García de Fanelli

Centro de Estudios de Estado y

Sociedad (CEDES) CONICET,

Argentina

Juan Carlos González Faraco

Universidad de Huelva, España

María Clemente Linuesa

Universidad de Salamanca, España

Jaume Martínez Bonafé

Universitat de València, España

Alejandro Márquez Jiménez

Instituto de Investigaciones sobre la Universidad y la Educación, UNAM, México

María Guadalupe Olivier Tellez, Universidad Pedagógica Nacional, México

Miguel Pereyra Universidad de

Granada, España

Mónica Pini Universidad Nacional de San Martín, Argentina

Omar Orlando Pulido Chaves

Instituto para la Investigación

Educativa y el Desarrollo Pedagógico (IDEP)

José Ignacio Rivas Flores

Universidad de Málaga, España
Miriam Rodríguez Vargas

Universidad Autónoma de

Tamaulipas, México

José Gregorio Rodríguez

Universidad Nacional de Colombia, Colombia

Mario Rueda Beltrán Instituto de Investigaciones sobre la Universidad y la Educación, UNAM, México José Luis San Fabián Maroto Universidad de Oviedo, España

Jurjo Torres Santomé, Universidad de la Coruña, España

Yengny Marisol Silva Laya

Universidad Iberoamericana, México

Ernesto Treviño Ronzón

Universidad Veracruzana, México

Ernesto Treviño Villarreal Universidad Diego Portales Santiago, Chile

Antoni Verger Planells Universidad Autónoma de Barcelona, España

Catalina Wainerman

Universidad de San Andrés, Argentina

Juan Carlos Yáñez Velazco

Universidad de Colima, México 


\section{arquivos analíticos de políticas educativas conselho editorial}

Editor Consultor: Gustavo E. Fischman (Arizona State University)

Editoras Associadas: Geovana Mendonça Lunardi Mendes (Universidade do Estado de Santa Catarina), Marcia Pletsch, Sandra Regina Sales (Universidade Federal Rural do Rio de Janeiro)

\author{
Almerindo Afonso \\ Universidade do Minho \\ Portugal \\ Rosanna Maria Barros Sá \\ Universidade do Algarve \\ Portugal \\ Maria Helena Bonilla \\ Universidade Federal da Bahia \\ Brasil
}

Rosa Maria Bueno Fischer Universidade Federal do Rio Grande do Sul, Brasil

\section{Alice Casimiro Lopes \\ Universidade do Estado do Rio de \\ Janeiro, Brasil \\ Suzana Feldens Schwertner \\ Centro Universitário Univates \\ Brasil \\ Flávia Miller Naethe Motta \\ Universidade Federal Rural do Rio de Janeiro, Brasil}

Alexandre Fernandez Vaz

Universidade Federal de Santa

Catarina, Brasil

\section{Regina Célia Linhares Hostins \\ Universidade do Vale do Itajaí, Brasil}

\section{Alfredo Macedo Gomes \\ Universidade Federal de Pernambuco Brasil}

\section{Jefferson Mainardes}

Universidade Estadual de Ponta

Grossa, Brasil

\section{Jader Janer Moreira Lopes}

Universidade Federal Fluminense e

Universidade Federal de Juiz de Fora, Brasil

\section{Debora Nunes}

Universidade Federal do Rio Grande do Norte, Brasil

\author{
Alda Junqueira Marin \\ Pontifícia Universidade Católica de \\ São Paulo, Brasil
}

Dalila Andrade Oliveira

Universidade Federal de Minas

Gerais, Brasil
José Augusto Pacheco

Universidade do Minho, Portugal

\section{Jane Paiva}

Universidade do Estado do Rio de Janeiro, Brasil

\section{Paulo Alberto Santos Vieira \\ Universidade do Estado de Mato \\ Grosso, Brasil}

Fabiany de Cássia Tavares Silva

Universidade Federal do Mato

Grosso do Sul, Brasil

\section{António Teodoro}

Universidade Lusófona

Portugal

\section{Lílian do Valle}

Universidade do Estado do Rio de Janeiro, Brasil

\author{
Alfredo Veiga-Neto \\ Universidade Federal do Rio Grande \\ do Sul, Brasil
}

